\title{
Physico-chemical characterization of liquid waste from sugar production unit labs in Zuenoula, Côte d'Ivoire
}

\author{
Atolé Brice Bienvenu KEDI*, Yao Francis KOUAME, Seka Simplice KOUASSI, \\ Alika Odile ABRY and Koffi Félix KONAN \\ Laboratory of Environmental Sciences and Technologies, University Jean Lorougnon GUEDE, UFR \\ Environment, BP 150 Daloa, Ivory Coast. \\ *Corresponding author; E-mail: brice.kedi@ujlg.edu.ci; Tel: (+225) 47938992
}

\begin{abstract}
Managing liquid waste from the laboratories of Integrated Agricultural Unit (IAU) of Zuénoula (Côte $\mathrm{d}$ 'Tvoire) is a major concern for the decision-makers of the company, who are working to solve this problem in their sustainable development policy. This work aims at quantifying liquid waste from the agronomic laboratories and factory of IAU of Zuénoula and to assess their level of pollution. The quantities of waste produced daily are estimated at $28.5 \mathrm{~L}, 52.6 \mathrm{~L}$ and $2600 \mathrm{~L}$ respectively for waste from the agronomy laboratory, the factory laboratory and from the rinsing water from latter's glassware. The following parameters were analyzed, temperature, $\mathrm{pH}$, conductivity, turbidity, total suspended solids, COD, BOD5, total nitrogen, total phosphorus, zinc, copper, lead and mercury. The results of these analyzes generally showed that waste produced did not comply with national standards. In particular, the level of lead was very high in these liquid wastes and reached 160 times the standard value. These results require a waste treatment system, which would reduce all the parameters, in particular those of the most noxious metals (lead and mercury).
\end{abstract}

(C) 2020 International Formulae Group. All rights reserved.

Keywords: Heavy metals, Pollution, Industrial unit, Ivorian standards, Wastewater.

\section{INTRODUCTION}

The impact of industrial effluents on the environment is today a pressing reality and a seriously threatens the quality of surface and ground waters in the long run (Gnagne et al., 2015; Ouedraogo et al., 2018). Almost all industrial activities using energy and raw materials in their processes produce waste and/or effluents, which are then found in natural environment. The fate of this waste and effluents varies according to the phases of product life cycle, depending on the raw materials used, product design and technology applied during its manufacture (Weidenhaupt and Meier, 2000). Such impacts, which may occur at local, regional or global levels, exert harmful or even dangerous effects on human health and environment. Thus, industrial development has led to worrying environmental situation for all those involved in economic, social and legal matters. It has been marked in recent years by the establishment of large factories, which discharge their liquid wastes into environment (Dhimni et al., 2015). These liquid wastes, if not treated before being discharged into nature, can seriously damage the ecosystem. In order to provide a best answer to the issue regarding the amount of waste generated by businesses and their specificities, the legislator has established comprehensive regulations in this area. Various international 
meetings on the environment have accelerated adoption of environmental legislation targeting sustainable development. Côte d'Ivoire, having ratified several treaties and conventions, has therefore passed laws in order to protect the environment, which industries are to abide by. The decree regulating discharges and emissions from amenities classified for protection of environment (MEF, 2008) was adopted on November 04, 2008 and henceforth published (Ivorian standard). These new provisions require the company to manage its waste. An environmental assessment, both quantitative and qualitative, is imperative and requires permanent monitoring to predict the trend in the receiving environment and thus recommend appropriate remedies (Zegaoula and Khellaf, 2014). Concerned with protection of environment, the IAU (Industrial Agricultural Unit) of Zuenoula (Côte d'Ivoire) considered that it is essential to quantify and to characterize its liquid discharges produced by their two laboratories (factory and agronomic activities) so as to set up a waste management system.

This paper aims at assessing the level of pollution of liquid waste from IAU laboratories on the environment. It specifically includes quantifying liquid waste produced and determining their physicochemical characteristics.

\section{MATERIALS AND METHODS Study zone}

The Integrated Agricultural Unit of Zuénoula is located $25 \mathrm{~km}$ from Zuénoula in Center-West of Côte d'Ivoire (Figure 1). It is geographically located between $7^{\circ} 30$ and $7^{\circ} 40$ north latitude, and between $6^{\circ} 5$ and $6^{\circ} 15$ west longitude, and located at $209 \mathrm{~m}$ altitude above the sea (Péné and Assa, 2003). The factory's sugar production campaign lasts about seven months in a year (from September to March).

\section{Liquid laboratory waste}

The liquid waste, constituting our working material, comes from the activities of two laboratories of the IAU of Zuénoula during the sugar production campaign (2018-
2019). The agronomic laboratory and the factory laboratory. Liquid waste from the agronomic laboratory is made up of rejections from analyses on sugar cane, leaves and soils. As for factory laboratory, the liquid waste comes from analyses of the cane juice produced and rinsing water from the lab's glassware after analysis.

The samples of these liquid wastes are named in this work by letters (A, B and C). Thus, the samples from all discharge from the agronomic laboratory are designated by the letter A, samples from the reading discharge from the factory lab are designated by the letter B and samples from the rinsing water from the of factory lab's sinks are designated by the letter $\mathrm{C}$.

\section{Quantification of liquid waste}

The quantities of liquid waste produced each day for forty-five days (45) during the production campaign were measured using a cylindrical container of known diameter. Measuring the level of liquid in container makes it possible to determinate the volume of liquid waste. Measurements have been made for the three sources of liquid waste production.

\section{Sampling methods}

The sampling was carried out for four weeks, during the production campaign, in a proportion of one liter per week for each of the three sources of liquid waste. The samples collected this way from each of the three sources (A, B and C) during the four weeks were mixed. Each mixture was the sampled in polyethylene bottles and stored in the freezer at 2 to $5{ }^{\circ} \mathrm{C}$. Great care has been taken to maintain clean conditions during the collection and handling of the samples, in order to minimize any possible contamination (Degrémont, 2005). In addition, all the samples were collected using pre-cleaned polyethylene bottles and acidified to $\mathrm{pH} 2$ with concentrated $\mathrm{HCl}$.

\section{Laboratory analysis}

Temperature, $\mathrm{pH}$, conductivity, total suspended solids (TSS) and turbidity were 
measured in the factory lab after sampling and before the samples were stored in the freezer. Determination of inorganic and organic parameters such as chemical oxygen demand (COD), biochemical oxygen demand (BOD5), total nitrogen, total phosphorus, mercury $(\mathrm{Hg})$, lead $(\mathrm{Pb})$, zinc $(\mathrm{Zn})$ and copper $(\mathrm{Cu})$ was carried out at the National Laboratory for tests, Quality, Metrologies and Analyses (LANEMA) in Abidjan. Determination of the different metals was carried out using Atomic Absorption Spectroscopy (AAS). The analysis methods used are mostly according to the ISO standard and are listed in Table 1.

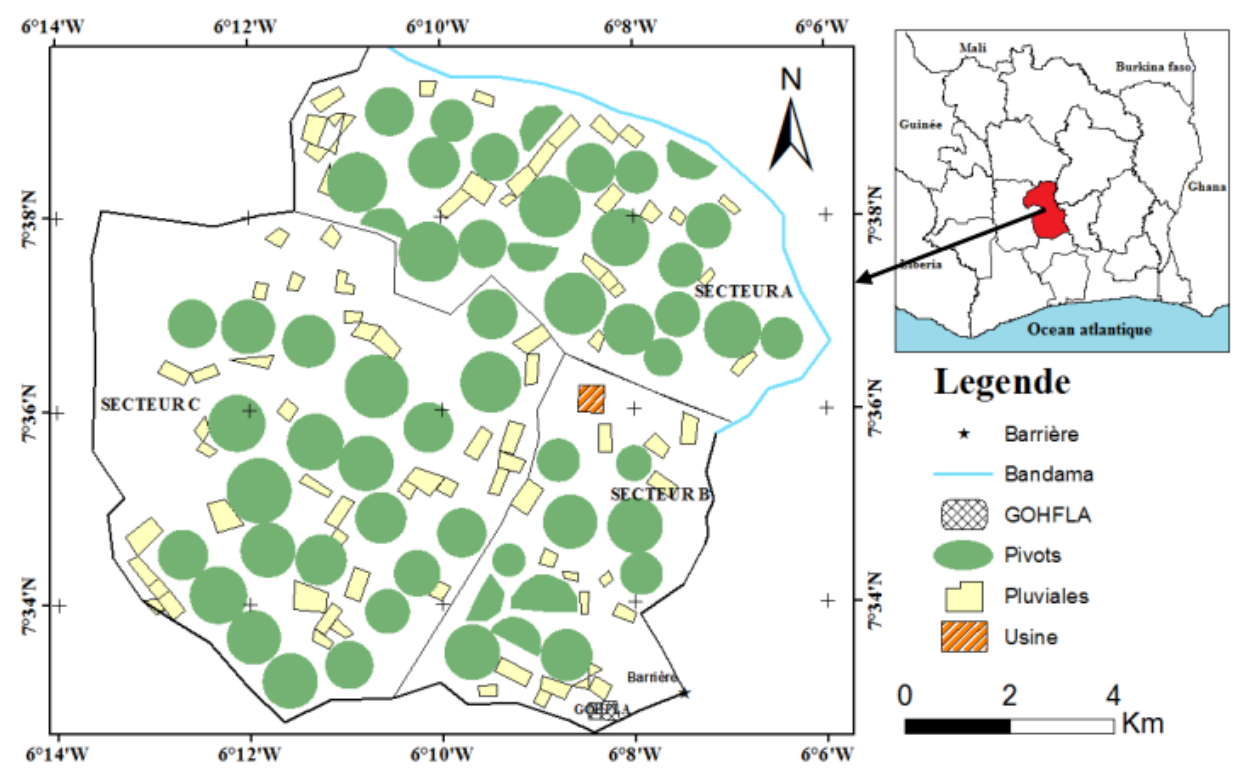

Figure 1: Map of the Integrated Agricultural Unit (IAU) of Zuénoula.

Table 1: Materials or methods of analyzing different parameters.

\begin{tabular}{lll}
\hline Parameters & Unit & Materials or methods used \\
\hline Temperature & ${ }^{\circ} \mathrm{C}$ & Knick-765 Laboratory pH Meter \\
$\mathrm{pH}$ & - & Knick-765 Laboratory pH Meter \\
Conductivity & $(\mu \mathrm{S} / \mathrm{cm})$ & multimeter Consort C933 \\
TSS & $(\mathrm{mg} / \mathrm{L})$ & multimeter Nalco DR/ 890 Colorimeter \\
Turbidity & $(\mathrm{NTU})$ & multimeter Nalco DR/ 890 Colorimeter \\
Total Phosphorus & $(\mathrm{mg} / \mathrm{L})$ & ISO 6878 v 2004 \\
Total nitrogen & $(\mathrm{mg} / \mathrm{L})$ & ISO 5663 v 1984 \\
COD & $(\mathrm{mg} / \mathrm{L})$ & ISO 6060 v 1989 \\
BOD5 & $(\mathrm{mg} / \mathrm{L})$ & Rodier $9^{\text {th }}$ edition \\
Copper & $(\mathrm{mg} / \mathrm{L})$ & Rodier $9^{\text {th }}$ edition \\
Zinc & $(\mathrm{mg} / \mathrm{L})$ & ISO 15586 v 2003 \\
Lead & $(\mathrm{mg} / \mathrm{L})$ & ISO 15586 v 2003 \\
Mercury & $(\mathrm{mg} / \mathrm{L})$ & Rodier $9^{\text {th }}$ edition \\
\hline
\end{tabular}




\section{RESULTS}

\section{Quantification of liquid waste}

The results of the daily quantity measurement of the liquid waste produced by agronomy and factory laboratories of IAU of Zuenoula over a period of forty-five days are shown in Figure 2.

The daily curve presenting quantities of waste from agronomic laboratory (Figure 2.1) shows that daily quantities vary greatly over the entire measurement period, from 0.005 to $0.061 \mathrm{~m}^{3}$, ie from 5 to 61 liters. The daily average over the 45 sampling period is $0.0285 \pm 0.015 \mathrm{~m}^{3}$, which is approximately 28.5 liters (Table 2). Figure 2.2 also shows how varied are daily quantities of liquid analytical waste produced by factory laboratory. These quantities vary from $0.007 \mathrm{~m}^{3}$ to $0.081 \mathrm{~m}^{3}$ over the measurement period with daily average of $0.0526 \pm 0.018$ $\mathrm{m}^{3}$ (Table 2), i.e. approximately 52.6 liters. The quantity of rinsing water from utensils used for analyses in the factory laboratory was captured once a week for four weeks and the results are shown in Figure 2.3. These results present quantities varying from week to week, from 2.24 to $3.04 \mathrm{~m}^{3}$ and an estimated daily average of $2.6 \pm 0.36 \mathrm{~m}^{3}$ (approximately 2,600 liters).

\section{Physico-chemical parameters of liquid waste}

To assess the environmental impact of the liquid waste produced by IAU laboratories, the main parameters indicating pollution have been measured and the results have been compared to the standard established by the State of Côte d'Ivoire. Results of temperature measurement, $\mathrm{pH}$, conductivity, turbidity, total suspended solids (TSS), COD, BOD5 and the COD / BOD5 ratio are captured in Table 3.

\section{Temperature}

The average temperature values of each of the three samples of liquid waste produced (A, B and C) are all below $30{ }^{\circ} \mathrm{C}$. These values do not exceed the maximum 40 ${ }^{\circ} \mathrm{C}$ recommended by Ivorian standards (MEF, 2008).

\section{Potential hydrogen (pH)}

The $\mathrm{pH}$ values of the three liquid wastes are between 4.37 and 4.54 . They are not within the range of values recommended by Ivorian standard (between 5.5 and 8.5). These $\mathrm{pH}$ values show that all the liquid waste produced is acidic and does not comply with the standards.

\section{Conductivity}

Although the conductivity of sample B is high $(3300 \mu \mathrm{S} / \mathrm{Cm})$, the one of sample A $(11820 \mu \mathrm{S} / \mathrm{Cm})$ is much higher with a more than 3.5 factor. Unlike the other two, sample $\mathrm{C}$ has a lower conductivity. These values show that the first two samples (A and B) are loaded with dissolved salts while sample $\mathrm{C}$ is less loaded $(540 \mu \mathrm{S} / \mathrm{Cm})$.

\section{Turbidity}

Turbidity measures the more or less cloudy appearance of the water. The results show that the liquid waste studied are very turbid with highest value for sample A equal to $5745 \mathrm{NTU}$, followed by $2160 \mathrm{NTU}$ for sample B. The sample C has a value of 262 NTU, lower than the other two.

\section{Total suspended solids (TSS)}

TSS values of the three samples are higher than the Ivorian standards (150 mg/L). However, the values of samples A (4035 $\mathrm{mg} / \mathrm{L})$ and $B(2150 \mathrm{mg} / \mathrm{L})$ are highest with factors of 27 and 14 respectively. As for sample C, the TSS value is $187 \mathrm{mg} / \mathrm{L}$ and slightly exceeds that of the standard. These values show that the samples are loaded with suspended solids. 


\section{Chemical oxygen demand (COD) and Biological oxygen demand (BOD5)}

The COD of sample C $(150 \mathrm{mg} / \mathrm{L})$ complies with to the standards as the value does not exceed the authorized $500 \mathrm{mg} / \mathrm{L}$. On the other hand, the COD of sample A (3000 $\mathrm{mg} / \mathrm{L})$ and $\mathrm{B}(1700 \mathrm{mg} / \mathrm{L})$ greatly exceed the maximum value authorized and are respectively 6 and 3 times higher than the standard. The BOD5 of samples A and B, respectively $2400 \mathrm{mg} / \mathrm{L}$ and $1500 \mathrm{mg} / \mathrm{L}$ are much higher than $150 \mathrm{~g} / \mathrm{L}$, which is the value set by the Ivorian standards. These values are respectively 16 and 10 times higher than standard. The BOD5 of sample $\mathrm{C}$ equal to 120 $\mathrm{mg} / \mathrm{L}$ and therefore meets the standards.

All the three samples have COD/BOD5 ratios less than 1.3 , which indicates that the organic matter in this wastewater are biodegradable. The biodegradability of organic matter in wastewater is effective when the COD/BOD5 ratio is estimated to be less than 2.5 (Dongo et al., 2013).

\section{Total phosphorus and Total nitrogen}

Figure 3 shows the total phosphorus values for the three samples. Apart from sample $\mathrm{C}$ which has a total phosphorus value lower than $15 \mathrm{mg} / \mathrm{L}$ (Ivorian standards), the values of the other samples $\mathrm{A}$ and $\mathrm{B}$ are higher than the maximum value authorized in Côte d'Ivoire. The same is true for measurement of total nitrogen. Only sample $\mathrm{C}$ meets the standard $(50 \mathrm{mg} / \mathrm{L})$ with a value of $2.10 \mathrm{mg} / \mathrm{L}$. The other two samples greatly exceed (more than 3 times) the value allowed.

\section{Metallic elements}

The analysis of the three samples of liquid waste revealed the presence of heavy metals including copper, zinc, lead, mercury. Copper and zinc concentrations, as illustrated in Figure 4, show that the values obtained for each of these parameters are significantly lower than the maximum limits recommended by the Ivorian standards namely $0.5 \mathrm{mg} / \mathrm{L}$ for copper, and $2 \mathrm{mg} / \mathrm{L}$ for zinc. However, lead and mercury concentrations widely exceed the maximum limit values $(0.5 \mathrm{mg} / \mathrm{L}$ for lead and $0.2 \mathrm{mg} / \mathrm{L}$ for mercury) before being released into the receiving environment.

Table 2: Mean daily quantity of liquid waste produced at the IAU of Zuenoula during the annual production campaign (September 2018 to March 2019).

\begin{tabular}{llll}
\hline Code & $\begin{array}{l}\text { Mean daily } \\
\text { quantity }\left(\mathbf{m}^{3}\right)\end{array}$ & Nature of waste & Waste origin \\
\hline A & $0,028 \pm 0,015^{\text {a }}$ & liquid waste of analysis & agronomy laboratory \\
B & $0,053 \pm 0,018^{\text {a }}$ & liquid waste of analysis & factory laboratory \\
C & $2,598 \pm 0,364^{\text {a }}$ & Glassware rinsing water & factory laboratory \\
\hline
\end{tabular}

${ }^{\mathrm{a}}$ standard deviation was calculed with microsoft excel 2016. 
Quantity of liquid waste A produced per day

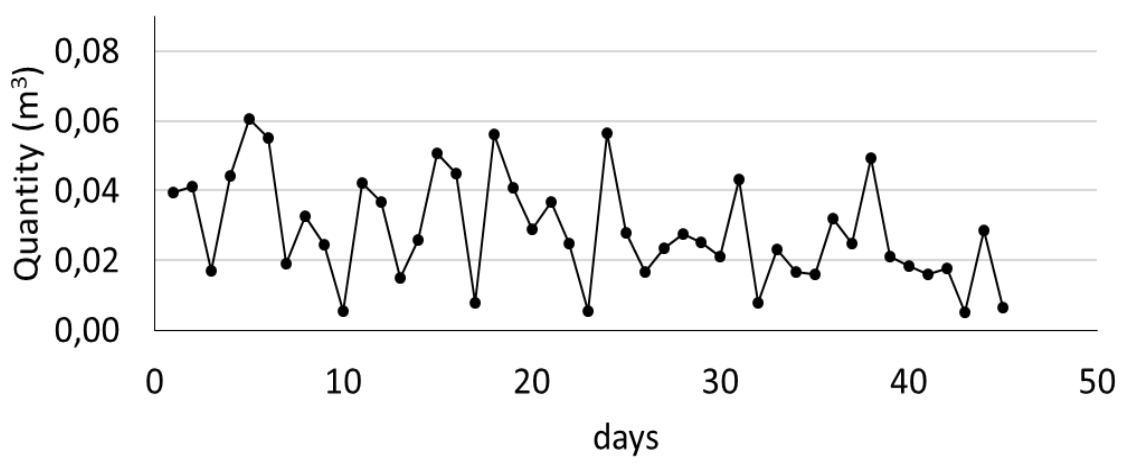

(1)

Quantity of liquid waste B produced per day

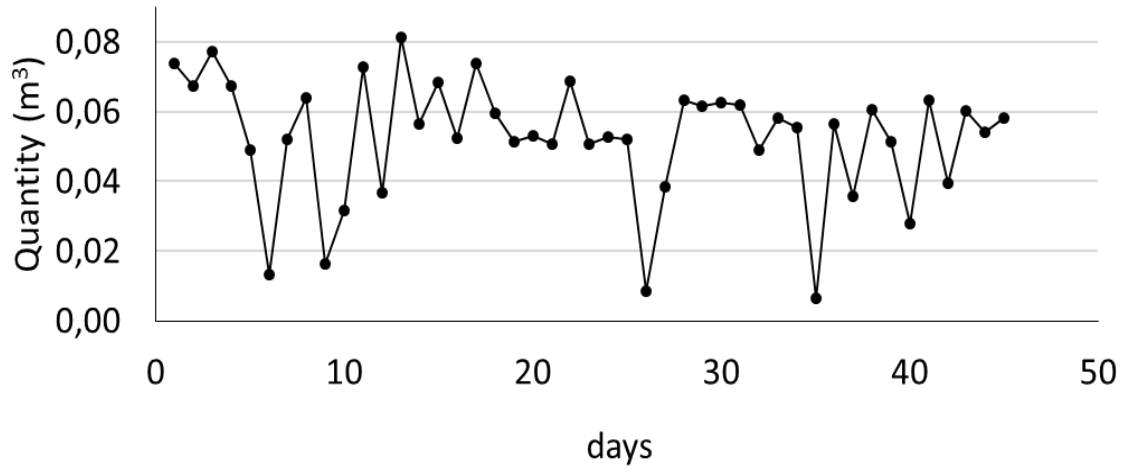

(2)

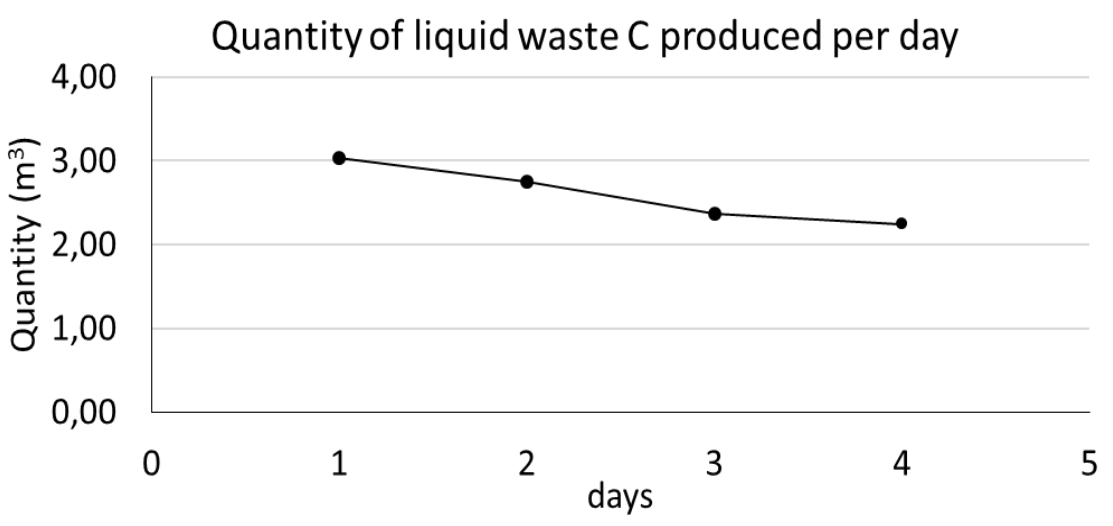

(3)

Figure 2: Quantity of liquid waste production per day in 1. agronomy laboratory (A), 2. factory laboratory (B) and 3. rinsing water of factory laboratory (C). 


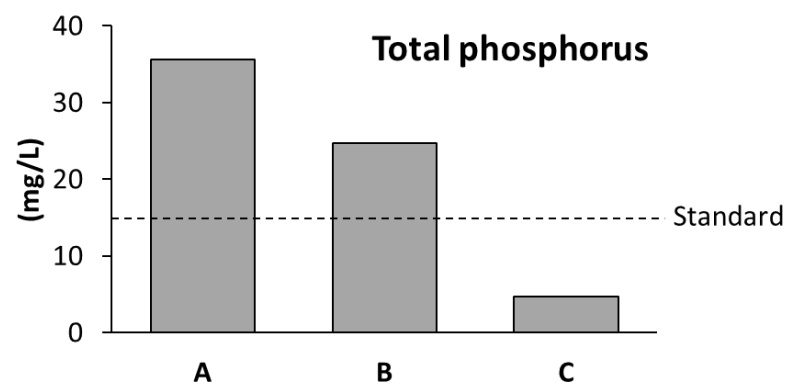

(1)

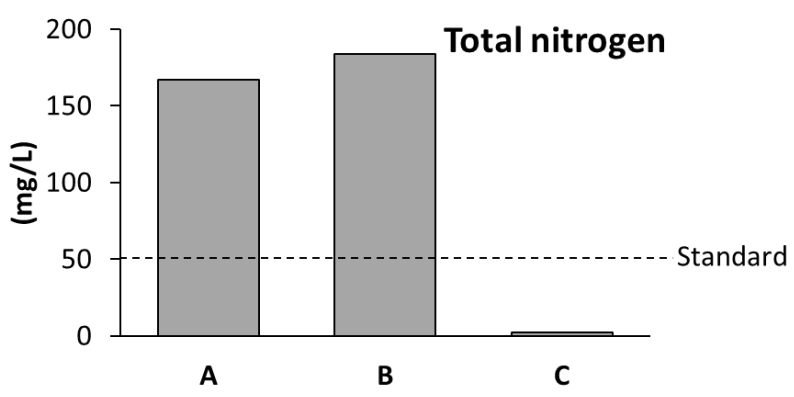

(2)

Figure 3: Concentration of 1. total phosphorus and 2. total nitrogen of liquid waste from agronomy laboratory (A), factory laboratory (B), rinsing water from factory laboratory (C) and Ivorian standard.
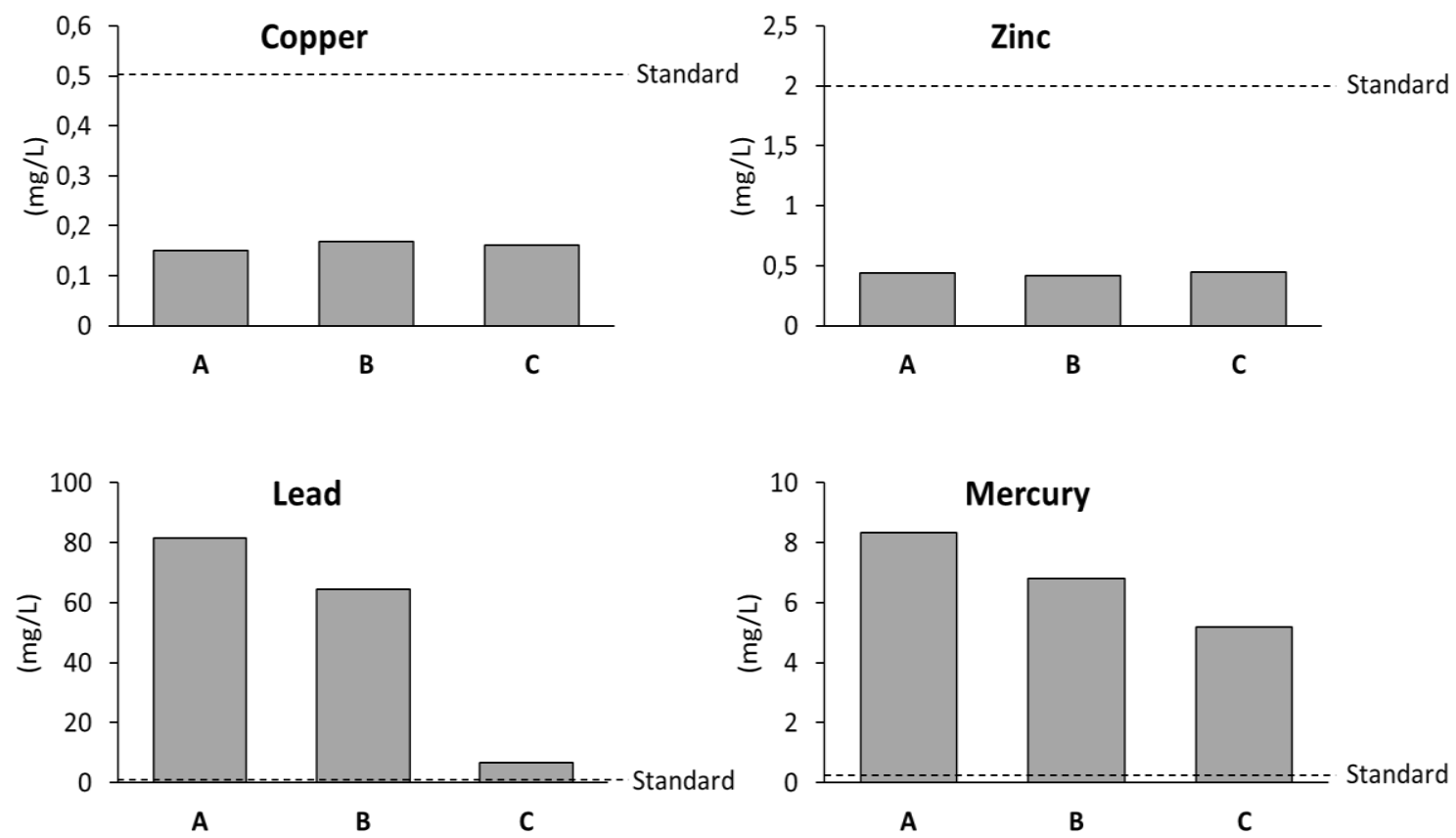

Figure 4: Concentration of heavy metals in liquid waste from agronomy laboratory (A), factory laboratory (B), rinsing water from factory laboratory (C) and Ivorian standard. 
Table 2: Physico-chemical parameters of liquid waste from agronomy laboratory (A), factory laboratory (B), rinsing water from factory laboratory (C) and Ivorian standard.

\begin{tabular}{lcccc}
\hline Samples & A & B & C & Ivorian standard \\
\hline Temperature $\left({ }^{\circ} \mathrm{C}\right)$ & 24 & 23,1 & 28 & 40 \\
$\mathrm{pH}$ & 4,48 & 4,37 & 4,54 & $5,5-8,5$ \\
Conductivity $(\mu \mathrm{S} / \mathrm{cm})$ & 11820 & 3300 & 540 & - \\
Turbidity $(\mathrm{NTU})$ & 5745 & 2160 & 262 & - \\
TSS $(\mathrm{mg} / \mathrm{L})$ & 4035 & 2150 & 187 & 150 \\
$\mathrm{COD}(\mathrm{mg} / \mathrm{L})$ & 3000 & 1700 & 150 & 500 \\
BOD5 $(\mathrm{mg} / \mathrm{L})$ & 2400 & 1500 & 120 & 150 \\
COD/BOD5 & 1,25 & 1,13 & 1,25 & 3,33 \\
\hline
\end{tabular}

\section{DISCUSSION}

Liquid waste from the agronomic laboratory comes mainly from analyses on sugar cane, cane leaves and soils. Analysis of cane leaves and soils makes determination of mineral elements they contain possible before proceeding to fertilization. In the same manners, sugar cane analysis allows us to follow the level of maturation and to determine sugar level before harvesting. The Liquid waste produced by the factory lab results from the different analyses at each stage of transformation of cane into finished product. These analyses are carried out daily throughout the sugar production campaign, which lasts approximately seven months a year (from September to March). The daily quantities of liquid waste generated by these laboratories during the production campaign are 28.5 liters, 52.6 liters and 2600 liters respectively for the agronomy laboratory (sample A), the factory laboratory (sample B) and for the rinsing water from the factory laboratory (sample C). the factory laboratory produces more liquid waste, compared to the agronomic laboratory. The quantity of liquid waste from the factory laboratory analyses is approximately 2 times higher than that from the agronomic laboratory. There are two reasons to this: either far more analyses are effected in this laboratory, which follows each stage of processing from cane to final sugar or this laboratory operates 24 hours a day all along a week during the production period, unlike agronomy laboratory, which does not work 24 hours a day, even as it works every day. The amount of rinsing water from utensils used for analyses in the factory laboratory is about 50 times higher than the liquid waste from these analyses.

The results of the analyses of two waste samples A and B from agronomy and factory laboratories show that the parameters studied do not comply with the Ivorian standards except temperature, copper and zinc concentration. However, concerning sample $\mathrm{C}$, less than half of the parameters studied does not meet the standards, namely $\mathrm{pH}$, TSS, lead and mercury. Thus, this liquid waste discharged into nature will be a source of pollution for the environment.

Measurement of the samples $\mathrm{pH}$ shows that they all have an acidic character $(\mathrm{pH}$ between 4.37 and 4.54). Such a value is below the biological range which is between 5.6 and 8.5 and which would enable the bacterial development necessary for the biological degradation of organic pollutants (Maïga et al., 2006). This acidic character is related to the presence in these releases of acidic chemicals such as sulfuric acid $\left(\mathrm{H}_{2} \mathrm{SO}_{4}\right)$, nitric acid $\left(\mathrm{HNO}_{3}\right)$, hydrochloric acid $(\mathrm{HCl})$, perchloric acid $\left(\mathrm{HClO}_{4}\right)$ which are strongest acids used in IAU laboratories.

In addition, the conductivity of liquid waste from the analysis activities of the agronomic (sample A) and factory (sample B) laboratories are respectively $11820 \mu \mathrm{S} / \mathrm{Cm}$ and $3300 \mu \mathrm{S} / \mathrm{cm}$, which indicates a high degree of mineralization and a high level of salinity in these discharges. This comes from the dissolution of chemical substances used 
for analyses and is also due to the presence of mineral elements. Mineral degree of sample A is 3 times higher than that of $\mathrm{B}$, thus indicating sample $\mathrm{A}$ is most charged with ions. The Ivorian standards is silent on the limit of the conductivity of wastewater; however, these values are higher than the limit value of direct discharge into the receiving environment, fixed at $3000 \mu \mathrm{S} / \mathrm{cm}$ in Morocco (Idrissi et al., 2015). The conductivity of factory laboratory rinse water (sample C) is low $(540 \mu \mathrm{S} / \mathrm{cm})$ and indicates a low concentration of ionic species in these releases.

Turbidity and TSS of samples A and B follow roughly the same trends with very high values for B and even higher for A. Turbidity and TSS of sample $\mathrm{C}$ are low compared to the other two samples. According to a study by Dongo et al (2013), the turbidity and TSS values of the three samples do not meet Ivorian standard unlike certain industrial effluents in Abidjan. The TSS values of this study can be compared to those found by Dhimni et al. (2015) on industrial liquid discharges in Morocco, which were between 4,500 $\mathrm{g} / \mathrm{mL}$ and 5,390 g/mL. Turbidity and TSS of liquid waste studied may be due to the presence of fine sugarcane fibers in the juices analyzed. In addition to the dark aspect of the discharges, a small part of turbidity may be due to the presence of colloidal materials of organic or mineral origin contained in discharges.

Likewise, concentrations of total phosphorus and total nitrogen in liquid waste studied exceed widely those set by the Ivorian standards except in sample C. These nutrients released in large quantities into environment are responsible for eutrophication. Nitrogen and phosphate are effective sources of nutrients for algae. The excessive presence of phosphate together with nitrates and potassium causes algal blooms, which cause the death of aquatic organisms (Bhateria and Jain, 2016). The high level of total phosphorus and total nitrogen can be explained, on the one hand by fertilization and soil amendments with fertilizers rich in phosphorus and nitrogen, and on the other hand by their presence in leaf solutions and the cane juices analyzed.
In addition, COD and BOD5 of samples studied, except sample C, greatly exceed those of the Ivorian standards set to 500 and $150 \mathrm{mg} / \mathrm{L}$ respectively. COD (3000 and $1700 \mathrm{mg} / \mathrm{L}$ ) and BOD5 (2400 and 1500 $\mathrm{mg} / \mathrm{L})$ values of our samples greatly exceed the values obtained for industrial wastewater according to the study of some authors. This is the case with the average COD and BOD5 values of $1180.64 \mathrm{mg} / \mathrm{L}$ and $728.17 \mathrm{mg} / \mathrm{L}$ respectively for industrial effluents in Abidjan (Dongo et al., 2013). The high COD and BOD5 values in our study indicate a strong presence of organic matter (Dhimni et al., 2015) but also of mineral elements. In fact, COD makes possible assessment of concentration of organic or mineral matter dissolved or suspended in water, by determining the amount of oxygen required for their total chemical oxidation. Like the BOD5, the COD is an indicator of organic water pollution and expresses the level of biodegradability of wastewater. The COD/BOD5 ratio gives values less than 2 for the different samples analyzed. The organic matter present in the liquid discharges studied is therefore easily biodegradable (Rodier et al., 2009). Indeed, a low value of the COD/BOD5 ratio implies the presence of a large proportion of biodegradable materials and makes it possible to envisage a biological treatment.

In addition, the results of the analyses reveal that the liquid waste from this study is contaminated with heavy metals such as copper, zinc, mercury and lead. However, copper and zinc levels are not alarming as they meet the standards $(0.5 \mathrm{mg} / \mathrm{L}$ for copper and $2 \mathrm{mg} / \mathrm{L}$ for zinc). In contrast, the IAU's liquid waste contains high concentrations of lead and mercury. Heavy metals are potentially toxic and their impacts can be felt in organisms at low doses (Todedji et al., 2020). Zinc, copper, lead and mercury are toxic at high concentrations (Aniyikaiye et al., 2019). Heavy metals are not biodegradable and therefore tend to accumulate in aquatic organisms (Malakootian et al., 2009). Sample $\mathrm{A}$ is the most contaminated with lead and mercury concentrations 160 times and 40 times higher than Ivorian standard. Sample B also contains very high values with 128 times and 34 times more than standard for lead and 
mercury respectively. However, sample $\mathrm{C}$ showed less amount than the other two, but contains considerably more amount than the authorized norm with values 13 and 26 times respectively higher for lead and mercury. Heavy metals such as zinc, copper, lead and mercury are often detected in wastewater or industrial effluents in several studies (Bawa et al., 2006; Chofqi et al., 2007; Iram et al., 2013). The presence of these heavy metals in liquid discharges is mainly due to the use of chemicals such as lead acetate (more than $80 \%$ used for clarification of cane juice), mercury chloride (used for conservation of sucrose in juice for later analyses) and copper sulfate (for analysis of reducing sugars). These heavy metals are also present in the standard solutions used for the various assays in the IAU laboratories regularly all along the production campaign. Int the light of the physico-chemical parameters results, a treatment of these liquid discharges is therefore necessary to avoid any pollution of the receiving environment. If the liquid waste produced by laboratories (sample A and B) are collected and treated separately, this is not be the case for the rinsing water from factory laboratory (sample C) which ends up directly in wastewater circuit of the IAU. The results of this study show that the rinsing water must not be neglected and must be taken into account in the treatment of the liquid waste because it contains pollutants.

\section{Conclusion}

The data from this study showed that the liquid waste produced by the agronomic and the factory laboratories does not meet national standards to be discharged into the environment. This waste is heavily laid with nitrogen, phosphorus, heavy metals (lead and mercury) and parameters for COD, BOD5, TSS, turbidity and conductivity are high and do not comply with the national standards. The non-standard values of these parameters show that this waste, produced in abundance on regard of its quantification, is a source of pollution if it is not treated before being discharged into the receiving environment. It is imperative to install a treatment system, which must not only reduce organic and mineral matters but also above all considerably reduce heavy metals, especially lead whose concentration is very high in liquid discharges. Such a system should reduce the values of parameters below the standards.

\section{COMPETING INTERESTS}

The authors declare that they have no competing interests.

\section{AUTHORS' CONTRIBUTIONS}

The main writing was done by ABBK. The results presentation (tables and figures) was carried out by SSK. AOA was responsible for the quantification of liquid waste and the collection of analyzed samples. YFK and KFK designed and planned this study.

\section{ACKNOWLEDGEMENTS}

We are grateful to Integrated Agricultural Unit (IAU) of Zuénoula for financial support and the National Laboratory for tests, Quality, Metrologies and Analyzes (LANEMA) for technical support.

\section{REFERENCES}

Aniyikaiye T, Oluseyi T, Odiyo J, Edokpayi J. 2019. Physico-Chemical Analysis of Wastewater Discharge from Selected Paint Industries in Lagos, Nigeria. International Journal of Environmental Research and Public Health, 16(7): 1235-1251. DOI: https://doi.org/10.3390/ijerph16071235

MEF (Ministère de l'Environnement et de la Foret). 2008. Arrêté $\mathrm{n}^{\circ} 01164$ du 04 novembre 2008, portant sur la réglementation des Rejets et Émissions des Installations Classées pour la protection de l'Environnement. Côte d'Ivoire, Abidjan.

Bawa ML, Djaneye-Boundjou G, Boukari Y. 2006. Caractérisation de deux effluents industriels au Togo: étude d'impact sur l'environnement. Afrique Science, 2(1): 57-68.

Bhateria R, Jain D. 2016. Water quality assessment of lake water: a review. Sustainable Water Resources Management, 2(2): 161-173. DOI : https://doi.org/10.1007/s40899-0150014-7 
Chofqi A, Younsi A, Lhadi EK, Mania J, Mudry J, Veron A. 2007. Lixiviat de la décharge publique d'El Jadida (Maroc) : caractérisation et étude d'impact sur la nappe phréatique. Déchets, Sciences et Techniques, 46 : 4-10. DOI : https://doi.org/10.4267/dechets-sciencestechniques. 1592

Degrémont S. 2005. Mémento technique de l'eau (Tome 1). Degrémont: ParisFrance.

Dhimni S, Qlihaa A, Qlihaa A, Chebabe D, Dermaj A, Hajjaji N. 2015. Caractérisation des rejets liquides d'une industrie d'emballage en carton. Journal of Materials and Environmental Science, 6(11): 3197-3206.

Dongo K, Niamke B, Adje A, Britton B, Nama L, Anoh K, Adima A, Atta K. 2013. Impacts des effluents liquides industriels sur l'environnement urbain d'Abidjan - Côte D'Ivoire. International Journal of Biological and Chemical Sciences, 7(1): 404-420. DOI: https://doi.org/10.4314/ijbcs.v7i1.36

Gnagne YA, Yapo BO, Meite L, Kouame VK, Gadji AA, Mambo V, Houenou P. Caractérisation physico-chimique et bactériologique des eaux usées brutes du réseau d'égout de la ville d'Abidjan. International Journal of Biological and Chemical Sciences, 9(2): 1082-1093. DOI:

http://dx.doi.org/10.4314/ijbcs.v9i2.44

Idrissi YA, Alemad A, Aboubaker S, Daifi H, Elkharrim K, Belghyti D. 2015. Physicochemical characterization of wastewater from Azilal city Morocco. International Journal of Innovation and Applied Studies, 11(3): 556-566.

Iram S, Kanwal S, Ahmad I, Tabassam T, Suthar V, Mahmood-ul-Hassan M. 2013. Assessment of physicochemical parameters of wastewater samples. Environmental Monitoring and Assessment, 185(3): 2503-2515. DOI: https://doi.org/10.1007/s10661-0122727-5

Maïga AH, Konaté Y, Wethe J, Denyigba K, Zoungrana D, Togola L. 2006. Performances épuratoires d'une filière de trois étages de bassins de lagunage à microphytes sous climat sahélien : cas de la station de traitement des eaux usées de l'EIER. Sud Sciences \& Technologies, 14: 1-9.

Malakootian M, Nouri J, Hossaini H. 2009. Removal of heavy metals from paint industry's wastewater using Leca as an available adsorbent. International Journal of Environmental Science \& Technology, 6(2): 183-190. DOI: https://doi.org/10.1007/BF03327620

Ouedraogo DB, Gnankambary Z, Nacro HB, SEDOGO MP. 2018. Caractérisation et utilisation des eaux usées en horticulture dans la ville de Ouagadougou au Burkina Faso. International Journal of Biological and Chemical Sciences, 12(16): 25642577.

DOI: https://dx.doi.org/10.4314/ijbcs.v12i6.8

Péné CB, Assa DA. 2003. Variations interannuelles de la pluviométrie et de l'alimentation hydrique de la canne à sucre en Côte d'Ivoire. Science et Changements Planétaires/Sécheresse, 14(1): 43-52.

Rodier J, Legube B, Merlet N. 2009. $L$ 'analyse de l'eau. Dunod : Paris.

Todedji JN, Degbey CC, Soclo E, Yessoufou A, Goudjo F, Hounfodji JW, Suanon F, Mama D. 2020. Caractérisation physicochimique et toxicologique des effluents des Centres Hospitaliers et Universitaires du département du Littoral du Bénin. International Journal of Biological and Chemical Sciences, 14(3): 1118-1132. DOI: https://doi.org/10.4314/ijbcs.v14i3.37

Weidenhaupt A, Meier AM. 2000. Analyse du cycle de vie Application aux systèmes de dépollution. Techniques de l'ingénieur Système de management environnemental produits et ACV base documentaire: TIB627. (ref. Article : g5810).

Zegaoula W, Khellaf N. 2014. Évaluation du degré de pollution des rejets liquides et atmosphériques du complexe fertialAnnaba (algerie). Larhyss Journal, 18: 77-91. 